\title{
South American Sea Lion Thanatocenotic Elements of in Sediments: Would be an Important Source of Environmental Contamination by Parasite Eggs?
}

\author{
Eliane Pereira ${ }^{1}$, Joana Echenique ${ }^{1}$, Laura Santos ${ }^{1}$, Daniela BrayerPereira ${ }^{1,2}$ and Ana Luisa Schifino Valente ${ }^{1,2 *}$ \\ ${ }^{1}$ Departamento de Parasitologia e Microbiologia, Universidade Federal de Pelotas, Brazil
}

${ }^{2}$ Programa de Pos-Graduacao em Parasitologia,Universidade Federal de Pelotas, Brazil

Submission: December 16, 2017; Published: March 12, 2018

*Corresponding author: Ana Luísa Schifino Valente, Campus Universitario S/N-CEP 96160-000 capao do Leao, Brazil, CP 354, Tel: +555332757339/7323; Email: schifinoval@hotmail.com

\begin{abstract}
Bodies of animals in decomposition on coastal sediment of beaches represent risk to public health. This work has as aim to verify if copses of South American sea lion in decomposition at beach may be an important source of parasite eggs contamination. Were studied 10 carcasses of o. flavescens in mild to moderate state of decomposition, found during systematic and weekly field trips in Brazilian south coast. Carcass faeces samples were aspirated and syringes, through the anus and rectum. A total of 40 sandy sediment samples around carcasses were analyzed. Additionally, 34 samples of faeces of live south sea lions were studied. Samples were processed using standard parasitological techniques. From faecal samples of live animals, immature females of $C$. austral were found. Helminthic or protozoa eggs were not found in none sample, neither in carcass nor in sandy sediment. This work points out that, in spite of $O$. flavescens show high helminthic infections, in the marine environment, the biotic and abiotic events, those occur since the death of the animal until the moment the carcass is deposited on the beach, contribute to the carcass does not be an expressive source of parasitic eggs dispersion, which may endanger public health.
\end{abstract}

Keywords: Parasite eggs; South american sea lion; Environmental contamination; Public health; Sandy sediment; Carcass

\section{Introduction}

Animal thanatocenotic elements represent an enormous risk to public health, since the degradation and recycling processes promoted by the decomposer invertebrates and microorganism's colonization until the total disappearance of organic wastes (thanatocenosis) are innumerable [1,2]. The South American sea lion, Otaria flavescens is apinniped often found in beaches from South Brazil [3]. Based on the number of animals' corpses found in the beaches, it is estimated the annual of mortality from 80 to 181 animals along about $230 \mathrm{~km}$ of continuous beaches [4] and the carcasses on the coastal sediment usually remain until their total decomposition [5]. Some beaches are not inhabited, but others are tourism references during the summer, with a great access of bathers. Studies in faecal samples of urban populations of 0 . flavescensin Chilean coast, revealed the zoonotic potential of several helminths, those could endanger public health [6]. Gastrointestinal of helminths of 0 . flavescensin South Brazil coast are composed by Corynosoma australe(Acanthocephala: Polymorphidae), Bolbosomaturbinella (Acanthocephala: Polymorphidae), Contracaeucumogmorhini (Nematoda: Anisakidae), Stephanoprora uruguayense (Digenea: Echinostomatidae), Diphyllobothrium sp. (Cestoda: Diphyllobothriidae) and Ascocotyle (Phagicola) longa (Digenea:
Heterophyidae). Parasite load, mainly by the acanthocephalan C. austra, which showed $100 \%$ of prevalence is as high as 1,756.04 worm by infected host [5]. This work investigated the existence of parasite eggs or even helminths in the sand around carcasses and faeces. Were studied ten carcasses of $O$. flavescens found during monitoring of the sandy beach strip, which extends $\left(31^{\circ} 21^{\prime} \mathrm{S}-51^{\circ} 02^{\prime} \mathrm{W}\right)$ to $\left(33^{\circ} 45^{\prime} \mathrm{S}-53^{\circ} 23^{\prime} \mathrm{W}\right)$. Only fresh carcasses or with mild decomposition state, level 2 to 3 , were used, according protocol adaptation [7]. Carcasses faeces samples were aspirated with $50 \mathrm{~mL}$ syringes, through rectum. A total of 40 coastal sediment samples, comprising four points around each carcass were collected each one with $225 \mathrm{~cm}^{3}$ of volume. The samples were collected at a distance of $10 \mathrm{~cm}$ of the following points: mouth, anus and right and left anterior flippers. The samples were processed using the technique of Caldwell \& Caldwell modified [8] to the helminth eggs and larvae, and oocysts of protozoa research. Additionally, 34 samples of faeces of live sea lions were collected from soil, during two expeditions in November 2016. The faecal samples of live and dead animals were processed using specific parasitological techniques [9-11]. The remaining content of each sample was washed in a $150 \mu \mathrm{m}$ aperture sieves and analyzed in an optical stereomicroscope (5-40 X), in order to research helminthes. The faecal analysis of 
live animals revealed the presence of organic fragments of food residues, such as bone, fish vertebrae, crystalline and otoliths. In only two samples, were observed the presence of $C$. australe immature females. Helminthic or protozoa (oocists) eggs were not found. In samples of faeces, collected from carcasses, were not found parasite eggs, as well as in the samples of sandy sediment. The absence of helminthic eggs in the samples of dead animals raises some questions that could be responsible for such results. The first point refers to the faeces volume, in the rectum, before the animal death. The samples varied from 1 to $6 \mathrm{~mL}$, with dilution when the volume was low, while in the coprological techniques the recommended amount of faeces is around 5-10g of faeces [1,2]. The death causes were not investigated, but most of the South American sea lions die due to the interaction with local fishing [3] and, frequently, the animals have content in their digestive tracts. Other causes associated to infectious pathologies, those could lead the animal to in appetence prior to death, are little known [12]. The low faeces volume decreased the probability of finding parasites eggs, even so it is surprising that no egg has been found, once the studies in feacal samples of sea lions and fur seals in rehabilitation, in the same geographical region, showed mainly ascarids and acanthocephalan eggs $[13,14]$. Another factor to consider is the influence of the constant sea washings, by the waves, in the time interval from the death until the deposit of the carcass on the beach and after this event. In case death and faecal ejection has occurred inside the water column, certainly, the faecal mass would be diluted and dispersed in sea waters. For that reason, would be more probable occur the beach contamination, when the death of the animals occurs on the sandy sediment. Lastly, an intermittence of postures of helminths could happen not coinciding with the moment of samples collection, eggs degradation due to the elapsed time since the death until the collection or, still, a different strategy of helminths dispersion, not the massive release of eggs in the faeces of its host. Due to the low number of samples, there is a probability, even if low that the posture of the helminths did not happen in the moment before the death of the specimens and then, the absence of eggs in the faeces can be explained. Once the faecal samples of the live animals were collected directed by environment, helminthic and protozoa eggs could suffer dehydration and lysis, because of solar exposition and partial dryness of the material.

\section{Conclusion}

This work points out that, in spite of the American south sea lions show high helminthic infections, in the marine environment, the biotic and abiotic events, those occur since the death of the animal until the moment the carcass is deposited on the beach, contribute to the carcass does not be an expressive source of parasitic eggs dispersion, which may endanger public health.

\section{Conflict of Interest}

There is no any economic or interest conflict in this manuscript publication.

\section{Acknoledgment}

To CNPq (Conselho Nacional de Desenvolvimento Científico e Tecnologico) and CAPES (Coordenacao de Aperfeicoamento de Pessoal de Nivel Superior) funding agencies of this work. Thanks go to Dra. Gertrud Muller for the careful revision of this manuscript.

\section{References}

1. Blauzius RD, Silva OS, Kauling AL, Rodrigues DFP, Lima MC (2006) Contaminacao da areia da praia do Balneario de Laguna, SC, por Ancylostomaspp. eToxocara spp. em amostras fecais de caes e gatos. Arquivos Catarinense de Medicina 35(3).

2. Matesco VC, Mentz MB, Root MB, Silveira CO (2006) Contaminacao sazonal por ovos de helmintos na praia de Ipanema, em Porto Alegre, Rio Grande do Sul. Brazil 35: 135-141.

3. Silva KG (2004) Os pinipedes no Brazil: Ocorrencias, estimativas populacionais e conservacao, Rio Grande: Universidade do Rio Grande.

4. Silva KG (2014) Os mamiferos marinhos do litoral sul do Rio Grande do sul. NEMA, Rio Grande, RS.

5. Pereira EM (2012) Identificacao da comunidade componente de helmintos gastrointestinais, hepaticos, pulmonares, cardiacos e renais de Otaria flavescens (leao-marinho-do-sul) no litoral sul do Brazil, Pelotas: Universidade Federal de Pelotas. Brazil.

6. Hermosilla C, Silva LMR, Navarro M, Taubert A (2016) Anthropozoonotic Endoparasites in Free-Ranging (Uban) South American Sea Lions (Otariaflavescens). Journal of Veterinary Medicine p. 1-7.

7. Geraci JR, Lounsbury VJ (2005) Decisions on the beach. In: Marine Mammals Ashore: A Field Guide for Strandings ( $2^{\text {nd }}$ edn). National Aquarium in Baltimore, Baltimore, Maryland, p. 371.

8. Correa GLB (1995) Contaminacao do solo por ovos, larvas de helmintos e oocistos de protozoarios, em pracas publicas de Santa Maria, RS, Brazil e sua importância em saude publica. Santa Maria: UFSM.

9. Gordon H McL, Whitlock, AV (1939) A new technique for counting nematode eggs in sheep feces, Journal Council Scientific Industry Research Australia12: 50-52.

10. Faust EC, Antoni D, Odom V, Miller MJ, Peres C, et al. (1938) A critical study of clinical laboratory technics for the diagnosis of protozoan cysts and helminth eggs in feces. Am J Trop Med Hyg 18(2): 169-183.

11. Sheather AL (1923) The detection of intestinal protozoa and mange parasites by a floatation technique. J CompPatholTher 36: 266-275.

12. Pereira CT,Amorim SD, Santos AFM, Siciliano S, et al. (2007) Vibriospp. isolados de mamiferos marinhos capturados na regiao litoranea do sudeste ao sul do Brazil. Pesquisa Veterinaria Brazileira 27(2): 81-83.

13. Jacobus K, Marigo J, Gastal SB, Taniwaki SA, Ruoppolo, et al. (2016) Identification of respiratory and gastrointestinal parasites of three species of pinnipeds (Arctocephalusaustralis, Arctocephalusgazella, and Otariaflavescens) in southern Brazil. J Zoo WildlMed 47(1):132-40.

14. DeCarli GA (2007) Parasitologia clinica: selecao de metodos e tecnicas de laboratorio para o diagnostico das parasitoses humanas $\left(2^{\text {nd }}\right.$ edn). So Paulo: Atheneu. 
This work is licensed under Creative Commons Attribution 4.0 Licens DOI: 10.19080/JDVS.2018.05.555657

\section{Your next submission with Juniper Publishers} will reach you the below assets

- Quality Editorial service

- Swift Peer Review

- Reprints availability

- E-prints Service

- Manuscript Podcast for convenient understanding

- Global attainment for your research

- Manuscript accessibility in different formats

( Pdf, E-pub, Full Text, Audio)

- Unceasing customer service

Track the below URL for one-step submission https://juniperpublishers.com/online-submission.php 